Language and Religion 


\section{Language Intersections}

Volume 2 


\section{Language and Religion}

Edited by

Robert A. Yelle

Courtney Handman

Christopher I. Lehrich

\section{DE GRUYTER}

MOUTON 
ISBN 978-1-61451-590-6

e-ISBN (PDF) 978-1-61451-432-9

e-ISBN (EPUB) 978-1-5015-0074-9

\section{Library of Congress Control Number: 2018956865}

\section{Bibliographic information published by the Deutsche Nationalbibliothek}

The Deutsche Nationalbibliothek lists this publication in the Deutsche Nationalbibliografie; detailed bibliographic data are available on the Internet at http://dnb.dnb.de.

(C) 2019 Walter de Gruyter Inc., Boston/Berlin Typesetting: Integra Software Services Pvt. Ltd. Printing and binding: $\mathrm{CPI}$ books $\mathrm{GmbH}$, Leck

www.degruyter.com 